\title{
Inculcating Character Values to the Student of Polytechnic ATMI Surakarta Vocational School
}

\author{
Fredericus P. Santoso*, Mulyoto, Djono, Muhammad Hanif \\ Department of Educational Technology, Faculty of Teacher Training and Education, Sebelas Maret University, Indonesia
}

Received December 9, 2019; Revised December 30, 2019; Accepted February 25, 2020

Copyright $\bigcirc 2020$ by authors, all rights reserved. Authors agree that this article remains permanently open access under the terms of the Creative Commons Attribution License 4.0 International License

\begin{abstract}
The objectives of this research are to find out: (1) the character education values, (2) the inculcation process of the character education values, and (3) the challenges in inculcating the character education values at Polytechnic ATMI Surakarta. This research was conducted using the phenomenological qualitative approach. The data were collected through interview, participative observation, and document analysis. Five educational administrators and four alumni were the respondents of this research. The data analysis was performed by interactive analysis of Miles and Huberman's model. The results of this research are as follows. Firstly, the values inculcated at Polytechnic of ATMI Surakarta character education are based on the Jesuit clergy. Secondly, the inculcation process of character education values at Polytechnic ATMI Surakarta is through micro-context and macro-context. The micro-context includes the integration of each subject, school culture, and self-development activities. The macro-context consists of family, school, and society. Third, the supporting factors and the challenging factors. The supporting elements are the interaction of teaching staff with students, facilities and infrastructure, educators, synergies between the school environment, family, community and industry, and academic and non-academic activities. The challenging factors are time allocation and focus on learning
\end{abstract}

Keywords Character Education, Character Values, Vocational Schools

\section{Introduction}

The process of character building in schools is essential because the school is expected to be a place of comprehensive education, both skills education and character development. Character development is also vital in preparing to enter the work realm, especially in vocational schools [1]. Character includes but is not limited to, courage, good judgment, integrity, politeness, kindness, perseverance, responsibility, tolerance, self-discipline, respect for school personnel, responsibility for school safety, service to others and good citizenship. A person's character refers to dispositions and habits that determine the way a person usually responds to wants, fears, challenges, opportunities, failures, and successes [2]. Thus, having a good, high, or honorable character is important to a person who is worthy of admiration and respect [3]. People with good character as individuals will know good, love good, and do good. It means developing the ability to summarize the situation, deliberately, choose the right thing to do and then do it. Zainal and Sujak [4] state that character refers to a series of attitudes, behaviors, motivations, and skills. While Almerico [5] defined that character education is a planned effort to make students know, care, and internalize values so that students behave as well human beings. Whereas some scholars argue that character education emphasizes exemplary, creating environment, and habituation [6]. Character education is also defined as a process of developing students regarding understanding, commitment, and the tendency [7] to behave under ethical values. This definition makes the role of educators have the most critical position in the process of learning character education because they will become mentors, examples and role models in developing student character. This modeling theory shows that humans who have good personalities can be used as good examples.

In developed countries, character education plays leading roles as developed nations not only have abundant natural resources but also are supported by the quality of human resources who can manage. To utilize the natural resource for the welfare and prosperity of the people needs human resources that have enough intelligence to manage. In addition to intelligence, good character is also required to complete the quality of human resources. It 
was stated that character foundations upon which a country rises to great heights. Taking away the character or morals, citizens will make countries fall. To produce quality and characterized human resources, there must be a synergy between family, school, and society, because the character starts with a habit. School is one of the strategic places in character building [8] in addition to family and community, through the school process of inculcating character values of students will be applied both through teaching and learning activities, school culture, and self-development activities [9].

As stated previously, the success of a nation in achieving national goals is not only determined by abundant natural resources but also by its human resources. Marcus Tullius Cicero, one of the primary founders of character education said that within the character of the citizen, and the welfare of the nation [10]. Cicero's opinion can be interpreted as if every citizen has a noble character the country will be prosperous. It also can be understood that human beings with character are human beings who, in every thought and action, will provide benefits and added value for their environment. Conversely, human thoughts and actions that have bad character will bring a lot of damage to the environment. If in a nation many people have lousy character, then the country will be wicked too.

The relationship between moral aspects and the progress of the nation was clearly reported. Character attributes like empathy (the ability to consider another's perspective), application (the ability to commit to a task), and self-regulation (the ability to control one's emotions) are correlated with higher educational attainment and better outcomes in the labor market [11]. Another report provides further context for the policy interested in schools offering their pupils character education, to support the development of moral integrity. The report describes concerns about a decline in the moral fabric of society, as is a result of increasing emphasis on material consumption and immediate self-gratification.

There are ten signs of the age deterioration of adolescents that must be watched out. It's not all teenagers who like that, but if the symptoms are already there, then that means that a nation is heading for destruction [12]. The ten signs are: 1) Violence and vandalism, 2) Stealing, 3) Cheating, 4) Disrespect for authority, 5) Peer cruelty, 6) Bigotry, 7) Bad language, 8) Sexual precocity and abuse, 9) Increasing self-centeredness and declining civic responsibility, 10) Self destructive behavior. Wardani explained that ten signs of human behavior that show the direction of destruction of the nation from Lickona are as follows: increased violence among students, use of language and bad words, influence / peer group strong in acts of violence, increased self-destructive behavior, such as drug use, alcohol and free sex, increasingly blurred guidelines for good and bad, decreasing work ethic, lower respect for parents and teachers, weak sense of individual and citizen responsibility, civilizing dishonesty, and the existence of mutual suspicion and hatred among others [13].

One step to anticipate those problems is to strengthen the terms of character education. Revitalization of Germany after the defeat of war with France was carried out with character and spirituality education, Japan faced urbanization along with the introduction of moral education, and America in the late twentieth century was full of various problems reintroducing character education [14].

The Presidential Regulation of the Republic of Indonesia number 87 of 2017 stipulates that Character Education Strengthening is an educational movement under the responsibility of educational units to strengthen students' character through harmonization of hearts, taste, thought, and sports with involvement and collaboration between educational, family and community units as part of the National Mental Revolution Movement. In this case the Government seeks and organizes a national education system that enhances faith and piety and noble character in order to educate the nation's life through civic education with the aim of developing capabilities and forming dignified national character and civilization in order to inform the nation's growth and improve potential students being a man of faith and piety to God Almighty, noble, healthy, knowledgeable, capable, creative, independent, and a democratic and responsible citizen. One of the steps taken is character education at Higher Education. Universities must take part in and take responsibility for developing and implementing character education to advance national civilization.

The Ministry of National Education, through the Directorate General of Higher Education, proposes an assimilative approach because it emphasizes integration. That is, character education is not taught as an independent subject to the level of other lectures, but is character building through various academic activities, both curricular, co-curricular, and extracurricular activities and can be integrated into learning in each subject [15]. All lecture materials related to norms or values need to be developed, expressed, and linked to the context of everyday life. Learning character values is not only in the cognitive order, but it touches on the internalization and real practice of everyday students' life in society. In addition, all members of the academic community (students, lecturers, and educational staff) are personality building agents.

Vocational education is a higher education diploma program that prepares students for jobs with specific applied skills to applied undergraduate programs [16]. Vocational education is another name for a long-known diploma program. However, after the education nomenclature becomes vocational education, usually tertiary education will undoubtedly improve the education system [17]. Contrary to the academic education system, 
vocational education applies an order of at least 60 percent practice and a maximum of 30 percent theoretical or ideally 70 percent practice and 30 percent theory. In addition, many universities also need cooperation with industries because there are many practices in the industry. Vocational High School (SMK) graduates will be more appropriate if they continue to a higher level since many universities now open this vocational school program. Students graduating from vocational education or vocational schools are now widely open to continue to higher levels such as D4 or applied bachelor, applied master, and also doctoral. The qualification level is determined by depth, complexity, and comprehensiveness of mastered knowledge. The level description can be divided into two parts, namely mastery of hard skills (theory and practice) and soft skills [18]. The depth of mastery of hard skills is given in phases while mastery of soft skills is done at all levels following the field being studied.

Based on the writer's observation, nowadays, character education is generally executed only in classrooms. This somehow burdens the students to develop, since what they need is freedom to move and behave the character, which needs to be actualized regularly. It is believed that character education implementation done in schools will be more effective if it is integrated with various subjects, not excluded into one single subject. It needs a depth observation to synthesis the implementation in vocational school.

The vocational school has a focus so that students have specific competencies that are ready to enter the work realm so that learning is a lot of practice. In this case, school graduates must have the character and competence in accordance with the needs of the work realm, such as good personal character, strong work characteristics and others. Polytechnic ATMI Surakarta in the city of Surakarta, Central Java Province, is a unique and exciting vocational school to be the object of research, one of which is because the polytechnic ATMI Surakarta was built by Jesuit clergy who saw the gap between graduates of Vocational High Schools and University in 1968.

The school is under the auspices of the Yayasan Karya Bakti Surakarta, which manages 2 schools, namely Mikael Vocational High School and polytechnic ATMI Surakarta. The existing department is related to the needs of the manufacturing industry. The curriculum used refers to the official curriculum of the Government, but it also develops a curriculum that is in line with the needs of the industrial world. On the basis above, this research is fascinating to do to get a form of character education that is in accordance with the needs of the work realm.

\section{Character Education}

The need for character education contained in Law of the Republic of Indonesia Number 20 of 2003 concerning the National Education System in article 3 states that: "National education functions to develop capabilities and shape dignified character and national civilization in order to educate the nation's life, aiming at developing potential students to become human beings who believe in and devote to God Almighty, have noble, healthy, knowledgeable, capable creative independent, and become democratic and responsible citizens. Based on the statement, it appears that the overall goal of national education is the development of student character.

Character is defined as a subjective assessment of one's personality related to personality attributes that can or cannot be accepted by society. It is a natural whole and a stable disposition that has been stable mastered, which defines an individual in his overall psychological behavior that makes it typical in the way of thinking and acting [19]. Based on that definition, a character refers to a series of attitudes, behaviors, motivations, and skills.

Characters come from Greek, which means "to mark" or mark and focus on how to apply the value of goodness in the form of actions or behavior. Based on this, it can be affirmed that it is a personality that makes a typical way of thinking and acting inherent in a person. Character consists of three behavioral shows consisting of moral knowledge, moral-based feelings, and moral-based behavior [20]. Good character consists of the process of knowing where it is good, the desire to do good, and doing good.

Character education is a planned effort in carrying out education to make students have good character. The scope of its implementation is not limited to the classroom learning process. The purpose of character education is to improve the quality of implementation and educational outcomes that lead to the achievement of the formation of character and noble character of students in a whole, integrated and balanced manner [21]. Through character education, students are expected to be able to independently improve and use their knowledge, study and internalize, and personalize the values of character and noble character so that it manifests in daily behavior.

Character formation must be carried out systematically and continuously that involves aspects of knowledge, feeling, loving, and action [22]. Furthermore, characters are developed through the stages of experience (knowing), implementation (acting), and habits. It means that character is not limited to knowledge. A person who knows right is not necessarily able to act according to his knowledge if he is not trained to do the right [4]. Characters reach the area of emotion and habits; thus, a functional character component is needed, namely knowledge about morals, feelings about morals, and moral actions. The Ministry of National Education Character Education Team explains that character development and development in schools are carried out in the following ways [23]: 


\section{Learning}

In addition to making students master the targeted competencies, earning activities are also designed to prepare students to know, realize care, internalize values, and shape behavior. In an integrated manner in learning, character education is the introduction of values, facilitation of obtaining awareness of the importance of values, and the internalization of values into the daily behavior of students through the learning process, both of those take place inside and outside the class on all subjects [24].

\section{Co-Curricular or Extracurricular Activities}

To implement co-curricular and extracurricular activities that support character education, they need to be supported by implementing guidelines, developing human resource capacity to support the implementation of character education and revitalizing existing co-curricular and extracurricular activities towards character development.

\section{Alternative Development and Character Building in Schools as the Actualization of School Culture}

At the institutional level, character education leads to the formation of school culture. School culture is a characteristic or character, and the image of the school in the eyes of the wider community. It is necessary to develop and foster character in the school as the actualization of school culture is an essential part of forming the character of students to be effective [25].

\section{Daily Activities at Home and in the Society}

Character education is not just knowledge, but it must be continued with efforts to foster a sense of love for good behavior and carried out every day as habituation. In this activity, the school can strive to create harmony between the characters developed in the school and habituation at home and society [26].

The success of character education in schools is indicated by changes in students' behaviors that can be seen with the following indicators: first, students are energetic, and have optimism and enthusiasm for learning, so that academic and non-academic challenges can be resolved well and with a happy heart. It even has the competitiveness to achieve achievements in every competition. Second, students have the principle that success is right, so they have confidence that success is something that can be achieved. In this case students have the initiative to study harder or make achievements to achieve their goals [27]. Without pressure or instructions from teachers, parents or other adults. Thirdly, students have high learning desires and do not assume that learning is only in the classroom, but always try to find answers to their ignorance, through a variety of information media, like from libraries, print media to ICT. They sharpen themselves to be more understanding, more mastered and more experts from the areas of interest that are favored and have a winning mentality and able to introspect themselves so they can prepare themselves to be more successful in the future.

The Research and Development Agency, Center of the Ministry of National Education has formulated character education material in the Indonesian context which covers 18 aspects as follows: religious (an attitude and behavior that is obedient in carrying out its religious teachings, tolerant of the implementation of other religious services, and living in harmony with other believers), honest (a behavior based on efforts to make himself a person who can always be trusted in words, actions, and work, tolerance, an attitude and action that respects differences in religion, ethnicity, ethnicity, opinions, attitudes, and actions of other people who are different from him), discipline (an action that shows an orderly behavior and adheres to various provisions and regulations), hard work (a behavior that shows genuine effort in overcoming various obstacles to learning and assignments, and completing tasks as well as possible), creative (a thinking process and doing something to produce new ways or results from something that has been owned), independent (an attitude and behavior that is not easily dependent on others in completing tasks), democratic (a way of thinking, behaving, and acting that values equal rights and obligations himself with others, curiosity is an attitude and action that always strives to know more deeply and extensively from everything that is learned, seen, and heard), the spirit of nationality (a way of thinking, acting, and insight that places the interests of the nation and State above the interests of themselves and their groups), nationality (a way of thinking, acting and acting that shows loyalty, caring, and a high appreciation of the language, physical, social, cultural, economic and political environment of the nation), appreciating achievement (an attitude and action that encourages them to produce something useful for the community, and acknowledging, and respecting the success of others), friendly or communicative (an action that shows pleasure in talking, associating, and working with others), peace (an attitude, words, and actions that cause other people to feel happy and secure over His presence), reading interest (a habit of providing time for reading various readings that give him good deeds), environmental awareness (an attitude and action that always strives to prevent damage to the surrounding natural environment, and develops efforts to improve the destruction of nature that has occurred), social awareness (attitude and actions that always want to provide assistance to other people and the people who need it, and responsibility is the attitude and behavior of a person to carry out their duties and obligations, which he should do, towards himself, society, environment, State and God [23]. Those 18 values formulated should be embedded in all educational institutions. 


\section{Polytechnic ATMI Surakarta}

Polytechnic ATMI Surakarta was established in 1968 by Jesuit clergy from Switzerland and Germany because of the educational gap between vocational graduates and University or Institute graduates. Since 1980, all teaching staffs are Indonesians who are graduates of ATMI and have obtained further education.

The role of Father J. Casutt inspired the development of education at the Polytechnic ATMI Surakarta, S. J, as such a great founding father through exemplary demonstrated to the entire academic community while serving as Director in 1971-2001. The example of Father J. Casutt, S.J is also transmitted to lecturers and instructors who are directly related to students. Discipline in the way of work even the experiences is stressed because nowadays free habits must be orderly. Use must be more careful because "fines, overtime" are introduced. The pattern of working regularly and cleanly is the main thing [28].

Lecturers and instructors are the leading examples of character education in learning as said by Teiseran [28] that the surrendering attitude was revealed in Sutardjo's habit of using the term of kudu iso (must be able). If asked why he likes to use the term must be able, he answered that because of his economical if not, there must be a reason why. If I have the intention, I should be able to, and if I want, it can happen. How we can judge that if we haven't done it is afraid that we will fail. I am against that thought. How can we say ora iso (can't), even though we haven't tried it yet. He also believes that the purpose of humanity is to serve and glorify God, the Creator. God is glorified if humans truly live fully, develop all the potential that is bestowed, and thus can be a channel of grace for as many people as possible.

Education at the Polytechnic ATMI Surakarta, not only educates students to be intellectually intelligent but also emotionally and spiritually wise. Intellectually intelligent is called competent. While being smart spiritually and emotionally is called character. Spiritual intelligence is built through an educational process that promotes aspirational insights and ethical insights. Emotional intelligence is shown by high work motivation, confidence, and the ability to work in a team. Intellectual intelligence or competence is a combination of physical and mental abilities, substantial knowledge, contextual knowledge, work experience, and manual skills [29].

As one of the vocational schools, practical learning at the Polytechnic ATMI Surakarta has a portion of $70 \%$, which is a course that adopts the standard competency requirements of manufacturing industries. Practical learning is also a training tool for students where the practice material provided is material that is in accordance with the demands of quality products produced by industry so that links and matches are formed between the world of education and the industry reflected in the education system based on Production Based Educational and Training (PBET). That practical learning is also a means of character development, which is the basis for developing the quality of life to enter the competitive world of industry [30].

\section{Materials and Methods}

\subsection{Research Type}

The method used in this research is a type of qualitative research with the "Phenomenology Approach." In qualitative research, researcher is a key instrument. The strength of the research method lies in the ability of researchers to enter the field of perceptions of others to see life as seen. In the method of phenomenological qualitative research, theory is born by itself or brought by a phenomenon that preaches itself. Phenomenology describes experience, not explaining or analyzing it [31]. The organizing and analyzing data in phenomenological studies began since researchers transcribed their interviews [32]. That process is summarized by steps of creating meaning units, clustering themes, and advancing textual and structural descriptions and presenting an integration of textual and structural descriptions into a description of essential invariant structure (or essence) of the experience [33].

\subsection{Time and Place of Research}

This research took place at the Polytechnic ATMI Surakarta, located in Surakarta City, Indonesia. The Polytechnic ATMI Surakarta was chosen as the research site because it has special characteristics, which are vocational colleges where the administrators are Jesuit clergy. The time for conducting this research is from October 2018 to March 2019.

\subsection{Subject and Object of Research}

The subject (respondent) in this research are people who have the capacity as a source of research information chosen purposively, while the research subjects in this study were Mr. R. Joko Priyono. as deputy director of Polytechnic ATMI Surakarta, Mr. Agung Kristanto as head of the Placement of Graduates, Mr. Yudha Samodra as head of Curriculum Development, Mr. Yuli Kristanto as an instructor, Mr. Yulius Igir as administrator of the Karya Bakti Surakarta Foundation, and Smy, Pjn, Prd, Prh, as an alumni of the Polytechnic ATMI Surakarta

The object in this research was the Polytechnic ATMI Surakarta students focused on the process of learning theory and practice, as well as self-development activities [34].

\subsection{Data Collection}

Data collection techniques in this research used: 1) 
participatory observation; 2) interviews; 3 ) documentation [35]. In qualitative research, data collection is done naturally as part of the social reality of education at the Polytechnic ATMI Surakarta.

Qualitative interviews were carried out on data sources. They are those selected people who are able to provide the necessary information or have experienced phenomena that are the focus of research and are willing to participate in the interview process. In this research, semi-structured interviews were used in the type of in-depth interview category to find problems more openly. The interviewees were asked for their opinions and ideas related to implementation of character education.

\subsection{Data Validity}

The technique of checking the validity of the data carried out in this research was by source triangulation, data triangulation and time triangulation which was part of the criteria of the level of confidence

\subsection{Data Analysis}

In this research, the data analysis technique used was the analysis model of Miles and Huberman, in which three main activities are interrelated and coincide, namely data reduction, data presentation, and conclusion or verification [36]. In this research, data reduction continued during the research process taking place at the Polytechnic ATMI Surakarta, then interpreted the data presented during the field and after leaving the field.

\section{Results and Discussion}

\subsection{Character Values of Polytechnic ATMI Surakarta Students}

Polytechnic ATMI Surakarta was founded by Catholic clergy from the Jesuit order, so that even though the Polytechnic ATMI Surakarta was not a religion-based school, it still had the essential characteristics of the
Jesuits because the first characteristic of character values instilled at Polytechnic ATMI Surakarta students through experience, where students have full learning experience in aspects of mind, heart and hands. Experience is an illustration that every activity, in addition to a cognitive understanding of the material being studied, students are also able to capture sensitivity. Experience is a critical element in education because learning experiences move students beyond knowledge into the development of increasingly complex learning abilities, understanding, application, analysis, evaluation.

The second characteristic that is key to the learning process is reflection. Reflection is the process by which students make their learning experiences their own, gain meaning from learning experiences for themselves and others. Reflection is intended as an in-depth consideration of material, experience, ideas, goals or spontaneous reactions, with the intention to fully absorb its significance. In this case, memory, understanding, imagination, and feeling are used to capture the meaning and intrinsic value of what is being studied, to find its relation to other aspects of human knowledge and activity, and to appreciate in the continuous search for truth and freedom. In addition, students consider the meaning and rationale meaning of what is learned and integrate that meaning as responsible students who grow up as competent, conscious and compassionate individuals.

The third characteristic is the action. Action is not just an activity but contains the attitudes, priorities, commitments, habits, values, ideals, human beings so that the internal growth of humans so he acts for others

The last characteristic is the evaluation of students' development in accepting school goals and the goals of the students themselves. It concerns the growth of students who are whole as individuals for others and cooperate with others (persons for and with others). So the periodic evaluation of students' growth in attitudes, priorities, and actions is consistent with the others and others as essential.

The characteristics of these Jesuits are manifested in everyday life in the form of honest, disciplined, hard work, creativity, and responsibility. 
Table 1. Character values of Polytechnic ATMI Surakarta

\begin{tabular}{|c|c|}
\hline Characters & Indicator \\
\hline Honest & $\begin{array}{l}\text { - } \quad \text { Do not attend to other people } \\
\text { - } \\
\text { - } \\
\text { - } \\
\text { - } \\
\text { - } \\
\text { - }\end{array}$ \\
\hline Discipline & $\begin{array}{ll}\text { - } & \text { Rate of attendance is } 100 \% \\
\text { - } & \text { Not late to come } \\
\text { - } & \text { Use of work safety tools in practical learning } \\
\text { - } & \text { Operation of equipment/machinery in accordance with the User Guide } \\
\text { - } & \text { Classes and laboratories are neat and clean } \\
\text { - } & \text { Use standards equipment }\end{array}$ \\
\hline Hard work & $\begin{array}{ll}\text { - } & \text { Try to make perfect results } \\
\text { - } & \text { Try to overcome learning problems } \\
\text { - } & \text { Enthusiastic in completing tasks } \\
\text { - } & \text { Looking for lots of references } \\
\text { - } & \text { Make important little notes } \\
\text { - } & \text { Dare to ask unknown things } \\
\text { - } & \text { The desire to learn is high } \\
\text { - } & \text { Complete each task } \\
\text { - } & \text { Discuss the problem }\end{array}$ \\
\hline Creative & $\begin{array}{ll}\text { - } & \text { Find the most practical steps } \\
\text { - } & \text { Dare to try new things } \\
\text { - } & \text { Make a small note when explained } \\
\text { - } & \text { Trying to find other learning resources } \\
\text { - } & \text { Enter the practice room } 5 \text { minutes before the lesson begins } \\
\text { - } & \text { Dare to ask things that are not clear } \\
\text { - } & \text { Dare to convey ideas }\end{array}$ \\
\hline Responsibility & 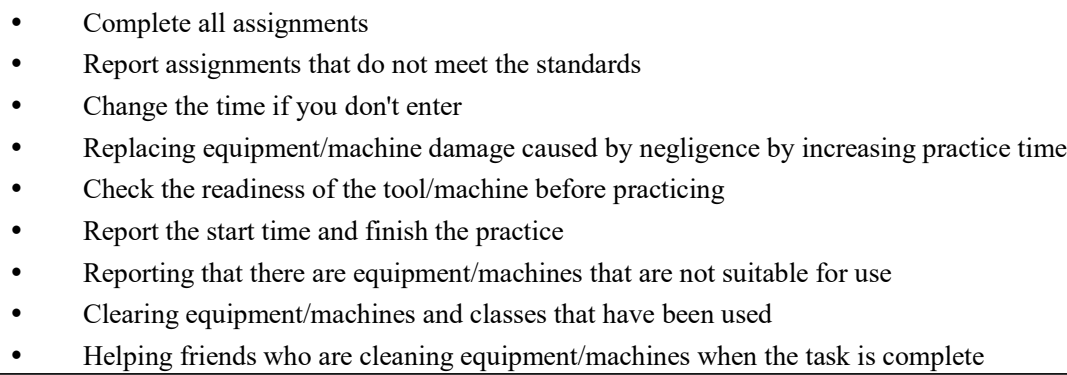 \\
\hline
\end{tabular}




\subsection{The Process of Inculcating Student's Character}

Based on document and interview analysis, this research found that the concept of inculcating the character values of the Polytechnic ATMI Surakarta students was implemented through two contexts, namely micro and macro contexts. Micro context is applied to a) integration in the subjects; b) school culture; and c) self-development activities.

The concept of process of inculcating character in Polytechnic ATMI can be resume in the figure below.

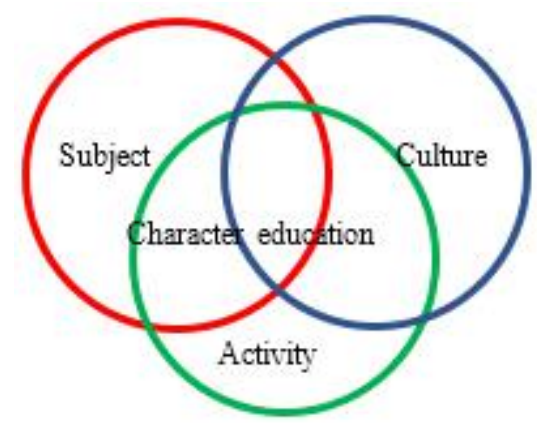

Figure 1. Concept of implementing character education in Polytechnic ATMI Surakarta

\subsubsection{Integration in Subjects}

Integration in courses and self-development through the curriculum used refers to the official curriculum of the Government, but it also develops curriculums that suit the needs of the industrial needs.

\subsubsection{School Cultures}

School culture is a tradition that is carried out daily because character values will never be engraved without habituation because school culture will affect students. Therefore, to implement in the implementation of student character education, the Polytechnic ATMI Surakarta consciously seeks to create a positive environment and culture for all components of the school (lecturers, instructors, students, and education staff). The educator culture and education of the Polytechnic ATMI Surakarta that the researchers found were as follows: a) pluralist culture: this can be shown in aspects, students respect each other despite having different religions. b) culture of work discipline: discipline is shown not only in the perspective of being on time but also in using equipment according to its function, especially in practical learning, lecturers and instructors come first and go home after students leave the room, this work discipline culture provides an excellent example for students always to be disciplined and right in everything; c) shame culture, there are 10 shame cultures applied at the Polytechnic ATMI Surakarta, namely: ashamed of being dishonest, embarrassed to be late in admission, ashamed of littering, ashamed to smoke in the school area, ashamed of not going to work, ashamed to work without a program, embarrassed to go home prematurely, ashamed to leave work, ashamed to work without responsibility, ashamed to dress uniformly or without attributes.

One of the steps of the Polytechnic ATMI Surakarta in implementing student character education is through a culture created in the student environment, namely: a) entering the class 5 minutes before the learning activities begin; b) greeting; c) using a vehicle safety tool and parking the vehicle in a neat place; d) praying before and after the completion of learning activities; e) maintaining order, security, and cleanliness of the classroom and school environment; f) not using communication device during the learning process; g) well-dressed and polite; h) orderly entering the course and other the teaching and learning process; i) asking permission before leaving during the learning process; $j$ ) maintaining cleanliness in the school environment by making trash; k) haircutting according to those prescribed for safety, l) nails cutting regularly; $\mathrm{m}$ ) obeying school rules.

\subsubsection{Self-Development}

The implementation of character education at the Polytechnic ATMI Surakarta was carried out also through self-development programs. The self-development program is a variety of programs organized by the school to support the development of student character and personality, and activities provide opportunities for students to express themselves according to their needs, talents, and interests in accordance with the conditions of the school.

Self-development activities in the form of extra-curricular activities are facilitated and guided by lecturers, or outside trainers who can be carried out in the way of extracurricular activities, while the self-development programs at Polytechnic ATMI Surakarta are: a) Basketball (one of the favorite self-development activities for students); This group practices regularly 2 times a week at the Sport Centre of the Polytechnic ATMI Surakarta. Once every 2 years, a tournament is held and attended by high school students in the city of Surakarta, and the entire organizing committee comes from students; (b) Futsal; Polytechnic ATMI Surakarta also has a futsal group as a means of self-development. Exercises are held at the futsal stadium around the campus or near the student domicile by renting. Activities are held once a week; c) Music; another means of self-development is playing music. The existing music groups at the Polytechnic ATMI Surakarta are Keroncong Music Group and Band Group.

Self-development in the form of co-curricular that must be followed by all students of Polytechnic ATMI Surakarta, namely: a) Spiritual Training grouped according to student religion. For those who are Muslims held in Islamic boarding schools under the guidance of clerics with the team, Catholics held at the retreat with the guidance of the Father with the team and those who are Christians are held at other retreat sites under the guidance 
of the priest with the team; b) Leadership Exercises; leadership exercises are held with the aim that students have the necessary provisions to become leaders. Mentoring is carried out by the Team from the Student Affairs field; c) Social Analysis; this activity was held to hone students' social sensitivity to real life in the community. Students are deployed and live together with one of the families (live in). The foster family come from small, weak, and low-income families, for example, factory workers, farm laborers, scavengers, and students live with the family to feel the dynamics and worldly life according to the family's habits. At the end of the step, there was a reflection guided by the Team from the field of Student Affairs.

In the macro context, planting the character values of the Polytechnic ATMI Surakarta students involve the family environment, school environment, and community environment. The roles of the family and community environment are as follows:

a) the role of the family: participate proactively in fostering and supervising their children outside of lecture hours, contributing to the development of schools and students, attending invitations to educative gathering once a year. In this educative gathering activity, there was not only a dialogue between parents and schools, but parents were also given the opportunity to see and assist their children in practical learning so that parents really could feel the experience experienced by students in learning. On the other hand, students feel they have received fully support and attention from their parents. Coordination, communication and consultation between parents and the school towards the development of their children is always done so that the synergy between family and school can be realized to achieve the formation of students with character;

b) the role of the community: participate in supervising students who do things that are not good, such as students who do not attend college, etc. In addition to the surrounding community who play a role in developing students, those who also play a role are industrial society, an industry not only provides employment opportunities for graduates but also participate in student development such as holding seminars with the theme of motivation, preparation for work realm, and others.

\subsection{Potential and Challenges in Inculcating Student's Character}

Supporting factors in planting character values at the Polytechnic ATMI Surakarta include 1) the interaction of teaching staff with students. The interaction between educators and students is quite close because the age is not too far apart; 2) facilities and infrastructure. Facilities in the form of workshops, laboratories, and spaces that can be used as places for the implementation of character education both individually and in groups; 3) Educators. Polytechnic ATMI Surakarta has adequate teaching staff and has the most crucial role in the learning process and the planting of character values, in this case the educator is open in helping solve problems faced by students, both in the context of learning and outside learning; 4) the existence of synergies between the school environment, family, community and industry; 5) The school supports to student development efforts with a variety of academic and non-academic activities.

The challenging factors in the planting of character values at the Polytechnic ATMI Surakarta include: 1) time allocation, the implementation of character education carried out during the learning process is considered to be less optimal, so it takes time outside the learning time, but if done outside the learning time, students already tired of extended learning and using many physical and mental activities; 2) the focus of learning. As a vocational school learning is more focused on psychomotor development of students where what is learned is material that is in accordance with industry standards so that the speed of completion with quality and industry standards becomes essential.

\section{Conclusions and Suggestions}

\subsection{Conclusions}

The research concluded that 1) Polytechnic ATMI Surakarta has implemented comprehensive way in instilling character education based on Jesuit clergy. The Jesuits values manifested in program are honest, disciplined, hard work, creativity, and responsibility. 2) The implementation of inculcating the character values of the Polytechnic ATMI Surakarta is taken through macro contexts. Micro context is implemented into integration in the subjects, school culture; and self-development activities. In the macro context, planting the character values of the Polytechnic ATMI Surakarta students involve the family, school, and community environment. 3) There are also supporting factors in planting character values at the Polytechnic ATMI Surakarta, they are the interaction of teaching staff with students, facilities and infrastructure, adequate educators, the synergies between the school environment, family, community and industry, and the school supports toward students' development efforts with a variety of academic and non-academic activities. There are also some challenging factors in the planting of character values at the Polytechnic ATMI Surakarta; they are time allocation and limit the focus of learning. Those unique values, successful implementation process and challenges faced by Polytechnic ATMI Surakarta can inspire other vocational school to develop their character education concepts. 


\subsection{Suggestions}

The findings as the meaning of this study are essential to be followed up. Firstly, for institutions, the integration of character education in learning needs to be developed, lecturers and instructors need to be given opportunities, support, and facilities to carry out character education in learning. Secondly, lecturers and instructors need to pay attention to character education in learning because it affects students' competencies. Implementation of character education in learning needs to be reviewed regularly. Thirdly, for students, character education in learning cannot be separated from skills development, so it needs to be carried out joyfully and continuously strived to internalize these character values so that they can develop intellectually, personally and socially.

\section{Acknowledgments}

We are very grateful to experts and respondents for their appropriate and constructive suggestions to improve this research.

\section{REFERENCES}

[1] C. R. Diggs and P. Akos, "The promise of character education in middle school: A meta-analysis," Middle Grades Review, vol. 2, no. 2, pp. 1-19, 2016.

[2] C. Pattarro, "Character education: Themes and researches. An academic literature review," Italian Journal of Sociology of Education, vol. 8, no. 1, pp. 6-30, 2016.

[3] A. Pala, "The need for character education," International Journal of Social Sciences and Humanity Studies, vol. 3, no. 2, pp. 23-32, 2011

[4] A. Zainal and Sujak, Guidance and application of character education (Panduan dan aplikasi pendidikan karakter), Bandung: Yama Widya, 2011.

[5] G. M. Almerico, "Building character through literacy with children's literature," Research in Higher Education Journal, vol. 26, pp. 1-13, 2014.

[6] L. Marshall, K. Rooney, A. Dunatchik and N. Smith, Survey of Character Education in Schools in England, London: DfE, 2017.

[7] T. C. Kose, "Character education of adolescents: A case study of a research center," Education and Science, vol. 40, no. 179 , pp. $295-306,2015$.

[8] L. Arofah, " Implementing character education through problem based learning in sociology subjects for the development of social capital," Vidya Karya Jurnal Kependidikan, vol. 30, no. 1, pp. 1-12, 2015.

[9] Zurqoni, H. Retnawati, J. Arlinwibowo and E. Apin, "Strategy and Implementation of character education in senior high schools and vocational high schools," Journal of Social Studies Education Research, vol. 9, no. 3, pp. 370-397, 2018.

[10] T. J. Husband, "Cicero and the moral education of youth," The Graduate School of Arts and Sciences Georgetown University, Washington, D.C., 2013.

[11] J. Birdwell, R. Scott and L. Reynolds, Character Nation. A Demos report with the Jubilee Centre for Character and virtues, London: Demos, 2015.

[12] T. Lickona, Character matters: how to help our children develop good judgment, integrity and other essential virtues, New York: Toughstone, 2004.

[13] N. S. Wardani, "Development of student character through project based learning for social studies subject," Jurnal Ilmiah Pendidikan, Sejarah dan Sosial Budaya, vol. 16, no. 2, pp. 103-115, 2014.

[14] Suyata, Character education: philosophic dimension in character education on theory and practices views (Pendidikan karakter: dimensi filosofis dalam pendidikan karakter dalam perspektif teori dan praktik, D. Zuchdi, Ed., Yogyakarta: UNY Press, 2011.

[15] W. Wardono, B. Waluya, K. Kartono, S. Sukestiyarno and S. Mariani, "The realistic scientific humanist learning with character education to improve mathematics literacy based on PISA," International Journal of Education and Research, vol. 3, no. 1, pp. 349-362, 2015.

[16] Kemenristekdikti, Guidance book of vocational education curriculum arrangement (Buku panduan penyusunan kurikulum pendidikan vokasi), Jakarta: Direktorat Jenderal Pembelajaran dan Kemahasiswaan Kementerian Riset Teknologi dan Pendidikan Tinggi, 2016.

[17] V. Deutscher and E. Winter, "Instructional sensitivity in vocational education," Learning and Instruction, vol. 53, pp. 21-33, 2018.

[18] Sunyoto, J. Widodo and Samsudi, "Development of Apprenticeship model for vocational school based on entrepreneurship," AIP Conference Proceedings, vol. 1941, pp. 1-8, 2018.

[19] Julia and T. Supriyadi, "The Implementation of Character Education at Senior High School," SHS Web of Conferences, vol. 42, no. 00085, pp. 1-6, 2018.

[20] Zubaedi, Character education design: concept and application in educational institution (Desain pendidikan karakter: konsepsi dan aplikasinya dalam lembaga pendidikan), Jakarta: Kencana, 2011.

[21] L. Abu, M. Mokhtar, Z. Hassan and S. Z. D. Suhan, "How to develop character of madrassa students in Indonesia," Journal of Education and Learning, vol. 9, no. 1, pp. 79-86, 2015.

[22] M. Muslich, Character education: breaking the challenge of multidimensional crisis (Pendidikan karakter: menjawab tantangan krisis multidimensial) Jakarta: Bumi Aksara., Jakarta: Bumi Aksara, 2011.

[23] Kemendiknas, The development of nation cultural and character education (Pengembangan pendidikan budaya dan karakter bangsa), Jakarta: Badan Penelitian dan Pengembangan Pusat Kurikulum dan Perbukuan, 2011. 
[24] Z. Çubukçu, "The effect of hidden curriculum on character education process of primary school students," Educational Sciences: Theory \& Practice, vol. 12, no. 2, pp. 1526-1534, 2012.

[25] Kemendiknas, Guidance of character education implementation based on experience of pilot educational institution (Pedoman pelaksanaan pendidikan karakter berdasarkan pengalaman di satuan pendidikan rintisan), Jakarta: Badan Penelitian dan Pengembangan Pusat Kurikulum dan Perbukuan, 2011.

[26] R. Thornberg and U. Oğuz, "Teachers' views on values education: A qualitative study in Sweden and Turkey," International Journal of Educational Research, vol. 59, no. 1, pp. 49-56, 2013.

[27] M. Chowdhury, "Emphasizing morals, values, ethics, and character education in science education and science teaching," The Malaysian Online Journal of Educational Science, vol. 4, no. 2, pp. 1-16, 2016.

[28] M. Teiseran, "Ab Initio Ad Esse," in Finding his world (Menemukan Dunianya), Bekasi, Tritoenggal, 2010, pp. 123-158.

[29] I. Farida, "Model of character education in higher education: startegic steps and implementation in university (Model pendidikan karakter di perguruan Tinggi: langkah strategis dan implementasinya di universitas)," Jurnal Ilmiah Administrasi Publik dan Pembangunan, vol. 3, no. 1, pp. 445-452, 2012.

[30] D. Morselli, M. Costa and U. Margiotta, "Entrepreneurship education based on the Change Laboratory," International Journal of Management Education, vol. 12, no. 3, pp. 333-348, 2014.

[31] B. Mudjiyanto and N. Kenda, "Metode fenomenologi sebagai salah satu metodologi penelitian kualitatif dalam komunikologi," Jurnal Penelitian Komunikasi dan Opini Publik, vol. 11, 2010.

[32] C. Moustakas, Phenomenological research methods, London: Sage Publications, 1994.

[33] J. Creswell, Reserach design qualitative \& quantitative approaches, California: Sage Publications, 1994.

[34] F. P. Santoso, Mulyoto and Djono, "A character education in vocational school as the provision for entering work realm," Advances in Social Science, Education and Humanities Research, vol. 326, pp. 216-219, 2019.

[35] Sugiyono, Educational research method: quantitative, qualitative and R\&D approaches (Metode penelitian pendidikan: Pendekatan Kuantitatif, Kualitatif, dan R \& D), Bandung: Alfabeta, 2011.

[36] B. Matthew, A. Miles and M. Huberman, Qualitative data analysis, London: Sage Publication Inc, 1994. 